\title{
Knowledge and Attitude of Organ Donation among Nursing Students of a College in Biratnagar
}

Binu Limbu ${ }^{1}$, Saraswati Basnet ${ }^{2},{ }^{\star}$ Suvekshya Silwal ${ }^{3}$

Authors Info:

${ }^{1}$ BNS Student,

${ }^{2}$ Lecturer,

${ }^{3}$ Instructor;

Tribhuvan University, Institute of

Medicine (IOM), Biratnagar Nursing

Campus, Biratnagar, Nepal

*Corresponding Author:

Ms Suvekshya Silwal

Email: suvusilwal@gmail.com

Disclaimer:

Conflict of Interest: None

Source of Support: None

Copyright (C) 2019 by author(s),

licensed under the Creative

Commons Attribution International

License 4.0 .

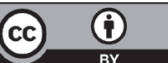

\begin{abstract}
:
Introduction: Organ transplantation is an effective therapy for end-stage organ failure. However, there is a large gap between the need for and the supply of donor organs. Nurses have a major role to play in tackling organ and tissue shortages. The main objective of the study was to assess the level of knowledge and attitude on organ donation among nursing students at Biratnagar.
\end{abstract}

Methodology: Descriptive cross-sectional study design among Post Basic Bachelor in Nursing (PBBN) students was carried out in Birat Health College, Biratnagar. Census method using self-administered semi-structured questionnaire was used for the data collection in 113 respondents. Descriptive statistics i.e., mean, median and standard deviation was used to assess the level of knowledge. Inferential statistics i.e., Chi-square test was used to find out the association between level of knowledge and attitude on organ donation with selected demographic variables.

Results: The findings of the study showed that out of 113 respondents, the mean age of respondents was 24.41 years. Similarly, $32.7 \%$ of the respondents were from 1st year, 33.6\% from 2 nd year and $33.6 \%$ from 3 rd year. More than half, (60\%) of the respondents were Brahmin/Chhetri. Similarly, (68.1\%) had heard about organ donation from colleagues. Among the studied respondents, (69.9\%) had average knowledge on organ donation and almost all (99.1\%) of respondents possessed positive attitude on organ donation.

Conclusion: The study concluded that respondents had positive attitude towards organ donation. However, only average knowledge regarding organ donation was found among respondents.

Key words: Attitude, Knowledge, Nursing students, Organ Transplantation, Organ Donation

\section{Article Info}

Received: October 11, 2019

Accepted: November 10, 2019

Published online: December 8, 2019

How to cite this article in Vancouver Style?

Limbu B, Basnet S, Silwal S. Knowledge and Attitude of Organ Donation among Nursing Students of a College in Biratnagar. Europasian J Med Sci 2019;1(1):28-34. https://doi.org/10.46405/ejms.v1i1.4

\section{Access this article online}

\section{Publisher Note:}

The Europasian Journal of Medical Sciences (EJMS) is an official Journal of Nirvana Psychosocial Care Center \& Ressearch Institute www.nirvanapscc.com. The Journal as well as publisher remain neutral with regards to any jurisdictional claims in any published articles, its contents and the institutional affiliations of the authors.
Quick Response (QR) Code

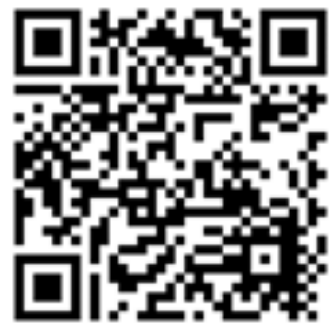

Scan Me for Full Text 


\section{BACKGROUND}

$\mathrm{T}$ he removal of tissue from human body that may be living or dead for the purpose of transplantation into another person as a treatment protocol is organ donation. The organs that can be donated and transplanted are: kidney, heart, liver, pancreas, intestine, lungs, skin, bone marrow, cornea, etc. ${ }^{1}$

There are two types of donors- Live donor and Cadaver donor (brain dead) these donors are further divided into two types of donor- Related donor and unrelated donor. $^{2}$ With the Dr. Joseph Murray's first kidney transplant recipient who lived for eight years, the promise of human organ transplant was empiric ally evidenced. However, because of the critical shortage of those life extending donor organs, the promise that donor organs can greatly extend one's life is not without challenge predominantly. ${ }^{3}$

In India, total 9.5 million deaths annually occurs due to organ failure which is nearly 100,000 and to save and extend lives, organ donation and organ transplantation have become the only hope where Health care professionals (HCPs) are key persons in facilitating the organ donation process. ${ }^{4}$

In Nepal, an estimated figure shows about 3,000 people develop kidney failure and incidence of liver failure as 1,000 per year respectively. Similarly, 30\% of the estimated diabetic population might be benefited from pancreas transplantation ${ }^{5}$. Nepali laws have restricted live organ donation only among close relatives, that is son, daughter, mother, father, brother, sister, uncle, nephew, niece, grandfather, grandmother from the father's side; grandson, grand-daughter from the son's side; grandson, grand-daughter from the daughter's side; and includes husband, wife, adopted son, adopted daughter, stepmother, stepfather, father-in-law, mother-in-law, with whom relationship has constantly existed since two years ago. ${ }^{6}$

There is limited supply of donors for organ transplantation all over the world to fulfill this increasing demand. This gap of demand and supply is the main obstacle to transplantation. There is lack of awareness and correct knowledge among public and due to religious and cultural barriers, myths and misconceptions regarding organ donation, there is still hesitancy in the donation of human organ. The countries, such as China, Japan, India and Pakistan, are among those where the knowledge and practices of organ donation is quite deficient. ${ }^{1}$
A study was conducted among 287 male and female students of 1st year medical, dental and nursing students of Madha Group of Educational Institutions and Tagore Medical College \& Hospital in Chennai, which showed that about $60 \%$ of the students had sufficient knowledge about the storage of harvested organs and compatibility check. About 90\% of them were aware of the need of organ donation and extended their support. They were quite unclear in the time lapse between harvesting and transplanting the organ; who could donate to whom, cadaver donations, methods and regarding the payment. ${ }^{7}$ The knowledge, attitude and behavior of healthcare professionals are important factors in fostering condusive environment to encourage and promote the importance of organ donation. $^{8}$

\section{MATERIALS AND METHODS}

$\mathrm{D}$ escriptive cross-sectional study design was used to assess the knowledge and attitude on Organ Donation among nursing students. The study was conducted in Province no. 1, Biratnagar Metropolitan city, in the Eastern region of Nepal at Morang District. Biratnagar being the center of education in the Eastern Developmental Region of Nepal, it has a good number of Hospitals, Medical Colleges and Educational Institutes as compared to other cities. The researcher purposively conducted study at Birat Health College where the PBBN students were enrolled. The study population was 1st, 2nd and 3rd year PBBN students from Birat Health College which had total of 113 students. As desired sample size was 99 and the total number of students in PPBN 1st, 2nd and 3rd year of Birat Health College was 113, so census method was used. Semi-structured questionnaire was as research instrument on the basis of objectives of research after reviewing various literatures and consulting with research guides and physician expert of related area.

Tools were divided into 3 distinct parts:

Part I: Socio-demographic information:

It included the respondent's age, ethnicity, academic year, work experience, area of work and training.

Part II: Knowledge on organ donation: Knowledge of the respondents was assessed through questionnaire regarding meaning of the terms "organ donation", "brain-death", awareness of donation by living people as well as cadavers, complications involved in organ donation, legal procedure of organ donation, etc. The knowledge section included 19 self-administered 
semi-structured questions with multiple response, multiple choice and dichotomous (Yes/No) question. Each question related to knowledge carried 1 mark and scoring was not done for source of information. In case of multiple responses for each correct response 1 mark was added. The total score for knowledge section was 49 . The scoring was based on classification of knowledge $e^{4}$ according to: Adequate Knowledge: $>75 \%$, Average Knowledge: 50\%-75\%, Inadequate Knowledge: $<50 \%$.

Part III: Attitude on organ donation: The level of attitude was determined through the both positive and negative statements where responses of each items was measured using 5 points Likert scale. The statements were regarding willingness to donate organs of self and family member's, influence of religion on attitude towards organ donation, perception regarding human body after donation, etc. The attitude questionnaire included 6 positive and 5 negative statements. For positive response: Strongly Agree $=5$, Agree $=4$, Uncertain $=3$, Disagree $=2$ and Strongly Disagree $=1$ whereas reverse scoring was done for negative response. The scoring was based on classification of Attitude ${ }^{9}$ according to: Positive Attitude: $\geq 60 \%$, Neutral: 30 $60 \%$, Negative Attitude: $<30 \%$.

The questionnaire was formulated in English and validated with English teacher for grammatical correction. It was developed on the basis of objectives of the study. Content validity of the instrument was maintained by extensive literature review, consulting with subject expertise and research advisor. Pretest was done on $10 \%$ of the sample size at Biratnagar Nursing Campus in the similar population for corrective purpose and that population was not included in data collection. Correction and modification of the questionnaire was done according to the need. Ethical principle was maintained throughout the study. Approval was taken from concerned department of Biratnagar Nursing Campus. Permission was taken from concerned authority of Birat Health College. Written informed consent was taken from each respondent. Privacy, confidentiality of information of all the respondents was maintained throughout the study. Respondents participated voluntarily and were allowed to discontinue at any point during the data collection period. Data was collected from the colleges with ethical consent from classroom respectively.

Collected data was checked daily for its completeness and accuracy. All the data was checked for completeness then editing and coding. Data processing was done by using computer Statistical Package for the Social Sciences (SPSS) version 16.0. Descriptive statistics i.e. frequency, percentage and mean were used to assess the level of knowledge whereas Inferential Statistics i.e. Chisquare test was used for finding association between knowledge and attitude on organ transplantation with selected socio-demographic variables.

\section{RESULTS}

Study finding shows that most of the respondents $S(76.1 \%)$ were from age-group 21-25 years. With regards to academic year, $32.7 \%$ of the respondents were from PBBN 1st year, $33.6 \%$ from 2 nd year and $33.6 \%$ from 3 rd year. More than half $(60 \%)$ of the respondents were Brahmin/Chhetri. Most of the respondents (94.7\%) worked for 1-5 years. More than half of the respondents (59.3\%) had worked in general ward whereas $40.7 \%$ had worked in ICU. None of the respondents $(100 \%)$ had ever received training on organ donation.

Table 1: Attitude on Organ Donation among Respondents ( $n=113)$

\begin{tabular}{|l|c|c|c|c|c|}
\hline Variable & $\begin{array}{l}\text { Strongly } \\
\text { agree f(\%) }\end{array}$ & Agree f(\%) & $\begin{array}{l}\text { Uncertain } \\
\mathrm{f}(\%)\end{array}$ & Disagree & $\begin{array}{l}\text { Strongly } \\
\text { disagree (\%) }\end{array}$ \\
\hline Support organ donation & $81(71.7)$ & $32(28.3)$ & - & - & - \\
\hline Donating organ add meaning to one's life & $76(67.3)$ & $36(31.9)$ & - & - & - \\
\hline Willing to donate organs after death & $33(29.2)$ & $50(44.2)$ & $21(18.6)$ & $6(5.3)$ & $3(2.7)$ \\
\hline Agree to donate family member's organ & $22(19.5)$ & $31(27.4)$ & $46(40.7)$ & $12(10.6)$ & $2(1.8)$ \\
\hline Organ donation insults human dignity\# & & $4(3.5)$ & $4(3.5)$ & $31(27.4)$ & $74(65.5)$ \\
\hline $\begin{array}{l}\text { Body will be left disfigured when organs are } \\
\text { removed\# }\end{array}$ & $3(2.7)$ & $13(11.5)$ & $16(14.2)$ & $45(39.8)$ & $36(31.9)$ \\
\hline $\begin{array}{l}\text { Live donation is better than dead donation } \\
\text { in solving the problems of organ shortage }\end{array}$ & $16(14.2)$ & $31(27.4)$ & $30(26.5)$ & $24(21.2)$ & $12(10.6)$ \\
\hline
\end{tabular}




\begin{tabular}{|l|l|l|l|l|l|}
\hline $\begin{array}{l}\text { Find organ donation unacceptable because } \\
\text { of religious beliefs }\end{array}$ & $46(40.7)$ & $43(38.1)$ & $7(6.2)$ & $16(14.2)$ & $1(0.9)$ \\
\hline $\begin{array}{l}\text { Feel uncomfortable to think or talk about } \\
\text { organ donation\# }\end{array}$ & $4(3.5)$ & $5(4.4)$ & $5(4.4)$ & $34(30.1)$ & $65(57.5)$ \\
\hline $\begin{array}{l}\text { Wealthy people and celebrities are given } \\
\text { more preference for organ donation\# }\end{array}$ & $21(18.6)$ & $36(31.9)$ & $12(10.6)$ & $24(21.2)$ & $20(17.7)$ \\
\hline $\begin{array}{l}\text { A deceased useful organ should not be } \\
\text { wasted, everyone should sign up for organ } \\
\text { donation }\end{array}$ & $47(41.6)$ & $46(40.7)$ & $8(7.1)$ & $8(7.1)$ & $4(3.5)$ \\
\hline
\end{tabular}

\# Negative statements

Table 1 shows the frequency and percentage of respondent's attitude towards each statement. In terms of positive statement, most of the respondents (71.7\%) strongly supported organ donation. More than half $(67.3 \%)$ of the respondents strongly agreed about donating organs adds meaning to one's life whereas less than half (44.2\%) of the respondents were willing to donate organs after death. Only $19.5 \%$ respondents strongly agreed to donate family member's organ. Similarly, only $14.2 \%$ respondents thought live donation better than dead donation in solving the problems of organ shortage. Less than half $(40.7 \%)$ of the respondents agreed that a deceased useful organ should not be wasted. In terms of negative statement, more than half (65.5\%) of the respondents strongly disagreed with the idea organ donation insults human dignity whereas $39.8 \%$ of the respondents disagreed that body will be disfigured when organs are removed. More than onethird (40.7\%) of the respondents found organ donation unacceptable because of religious belief. More than half (57.5\%) of the respondents felt uncomfortable to think or talk about organ donation whereas $31.9 \%$ of the respondents answered wealthy people and celebrities are given more preferences for organ donation.

Table 2 describes the association between level of knowledge with selected demographic variables which was calculated by using chi-square test and revealed that ethnicity is significant with the $\mathrm{p}$ value $<0.05$.

However, age, academic year, work experience and area of work is not significant as $p$ value is $>0.05$.

Table 4 describes the association between level of knowledge with selected demographic variables which was calculated by using chi-square test and revealed that ethnicity is significant with the $\mathrm{p}$ value $<.05$. However, age, academic year, work experience and area of work is not significant as p value is > 05 .

Table 2: Association between Knowledge and Selected Demographic Variables among Respondents $(n=113)$

\begin{tabular}{|c|c|c|c|}
\hline Variables & \multicolumn{2}{|c|}{ Level of Knowledge } & p-value \\
\hline \multicolumn{4}{|l|}{ Age (in years) } \\
\hline$<24$ & $1(0.9 \%)$ & $1(0.9 \%)$ & 0.422 \\
\hline$>24$ & $85(75.2 \%)$ & $26(23.0 \%)$ & \\
\hline \multicolumn{4}{|l|}{ Academic year } \\
\hline PBBN 1st year & $27(23.9 \%)$ & $10(8.8 \%)$ & \\
\hline PBBN 2nd year & $31(27.4 \%)$ & & 0.626 \\
\hline PBBN 3rd year & $28(24.8 \%)$ & & \\
\hline \multicolumn{4}{|l|}{ Ethnicity } \\
\hline $\begin{array}{l}\text { Brahmin/ } \\
\text { Chhetri }\end{array}$ & $51(45.1 \%)$ & $9(8.0 \%)$ & \\
\hline Others $^{* *}$ & $35(31.0 \%)$ & $27(23.9 \%)$ & $0.022^{*}$ \\
\hline \multicolumn{4}{|c|}{ Work experience } \\
\hline$<5$ years & $80(70.8 \%)$ & $27(23.9 \%)$ & \\
\hline$>5$ years & $6(5.3 \%)$ & $0(0.0 \%)$ & \\
\hline \multicolumn{4}{|l|}{ Area of work } \\
\hline $\begin{array}{l}\text { General } \\
\operatorname{ward}^{+* *}\end{array}$ & $49(43.4 \%)$ & $18(15.9)$ & 0.333 \\
\hline $\begin{array}{l}\text { Intensive Care } \\
\text { Unit }\end{array}$ & $37(32.7 \%)$ & $9(8.0 \%)$ & \\
\hline
\end{tabular}

* Significant association $\mathrm{p}$ value $<0.05$

** (Dalit, Janajati, Madhesi and Muslim)

*** (Medicine, surgery, neurosurgery, pediatric, psychiatric, Maternity and Operation theatre)

Table 3 shows the frequency and percentage of respondent's attitude towards each statement. In terms of positive statement, most of the respondents (71.7\%) strongly supported organ donation. More than half $(67.3 \%)$ of the respondents strongly agreed about donating organs adds meaning to one's life whereas less than half $(44.2 \%)$ of the respondents were willing 
to donate organs after death. Only $19.5 \%$ respondents strongly agreed to donate family member's organ. Similarly, only $14.2 \%$ respondents thought live donation better than dead donation in solving the problems of organ shortage. Less than half $(40.7 \%)$ of the respondents agreed that a deceased useful organ should not be wasted.

Table 3: Attitude on Organ Donation among Respondents $(\mathrm{n}=113)$
In terms of negative statement, more than half (65.5\%) of the respondents strongly disagreed with the idea organ donation insults human dignity whereas $39.8 \%$ of the respondents disagreed that body will be disfigured when organs are removed. More than one-third (40.7\%) of the respondents found organ donation unacceptable because of religious belief. More than half $(57.5 \%)$ of the respondents felt uncomfortable to think or talk about organ donation whereas $31.9 \%$ of the respondents answered wealthy people and celebreties are given more preferences for organ donation.

\begin{tabular}{|l|l|l|l|l|l|}
\hline \multicolumn{1}{|c|}{ Variables } & \multicolumn{1}{|c|}{$\begin{array}{c}\text { Strongly } \\
\text { agree(\%) }\end{array}$} & Agree (\%) & $\begin{array}{c}\text { Uncertain } \\
(\%)\end{array}$ & $\begin{array}{l}\text { Disagree } \\
(\%)\end{array}$ & \multicolumn{1}{|c|}{$\begin{array}{c}\text { Strongly } \\
\text { disagree } \\
(\%)\end{array}$} \\
\hline Support organ donation & $81(71.7)$ & $32(28.3)$ & - & - & - \\
\hline Donating organ add meaning to one's life & $76(67.3)$ & $36(31.9)$ & - & - & $1(0.9)$ \\
\hline Willing to donate organs after death & $33(29.2)$ & $50(44.2)$ & $21(18.6)$ & $6(5.3)$ & $3(2.7)$ \\
\hline Agree to donate family member's organ & $22(19.5)$ & $31(27.4)$ & $46(40.7)$ & $12(10.6)$ & $2(1.8)$ \\
\hline Organ donation insults human dignity\# & - & $4(3.5)$ & $4(3.5)$ & $31(27.4)$ & $74(65.5)$ \\
\hline \hline Disfigured body when organs removed\# & $3(2.7)$ & $13(11.5)$ & $16(14.2)$ & $45(39.8)$ & $36(31.9)$ \\
\hline Live donation is better & $16(14.2)$ & $31(27.4)$ & $30(26.5)$ & $24(21.2)$ & $12(10.6)$ \\
\hline Organ donation \# & $46(40.7)$ & $43(38.1)$ & $7(6.2)$ & $16(14.2)$ & $1(0.9)$ \\
\hline Feel uncomfortable about organ donation\# & $4(3.5)$ & $5(4.4)$ & $5(4.4)$ & $34(30.1)$ & $65(57.5)$ \\
\hline More preference to wealthy people\# & $21(18.6)$ & $36(31.9)$ & $12(10.6)$ & $24(21.2)$ & $20(17.7)$ \\
\hline Use of deceased organ & $47(41.6)$ & $46(40.7)$ & $8(7.1)$ & $8(7.1)$ & $4(3.5)$ \\
\hline
\end{tabular}

Table 4: Association between Knowledge and Selected Demographic Variables among Respondents $(\mathrm{n}=113)$

\begin{tabular}{|c|c|c|c|}
\hline \multirow[t]{2}{*}{ Variables } & \multicolumn{2}{|c|}{ Level of Knowledge } & \multirow[t]{2}{*}{ p-value } \\
\hline & $\begin{array}{c}\text { Adequate } \\
(\%)\end{array}$ & $\begin{array}{c}\text { Inadequate } \\
(\%)\end{array}$ & \\
\hline \multicolumn{4}{|l|}{ Age (in years) } \\
\hline$<24$ & $1(0.9 \%)$ & $1(0.9 \%)$ & .422 \\
\hline$>24$ & $85(75.2 \%)$ & $26(23.0 \%)$ & 0.626 \\
\hline \multicolumn{4}{|l|}{ Academic year } \\
\hline PBBN 1st year & $27(23.9 \%)$ & $10(8.8 \%)$ & $.022^{*}$ \\
\hline PBBN 2nd year & $31(27.4 \%)$ & $7(6.2 \%)$ & .333 \\
\hline PBBN 3rd year & $28(24.8 \%)$ & $10(8.8 \%)$ & 0.501 \\
\hline \multicolumn{4}{|l|}{ Ethnicity } \\
\hline $\begin{array}{l}\text { Brahmin/ } \\
\text { Chhetri }\end{array}$ & $51(45.1 \%)$ & $9(8.0 \%)$ & \\
\hline Others ${ }^{* *}$ & $35(31.0 \%)$ & $27(23.9 \%)$ & \\
\hline
\end{tabular}

\begin{tabular}{|c|c|c|}
\hline \multicolumn{3}{|l|}{$\begin{array}{l}\text { Work } \\
\text { experience }\end{array}$} \\
\hline$<5$ years & $80(70.8 \%)$ & $27(23.9 \%)$ \\
\hline$>5$ years & $6(5.3 \%)$ & $0(0.0 \%)$ \\
\hline \multicolumn{3}{|l|}{ Area of work } \\
\hline General ward $^{* * *}$ & $49(43.4 \%)$ & $18(15.9)$ \\
\hline $\begin{array}{l}\text { Intensive Care } \\
\text { Unit }\end{array}$ & $37(32.7 \%)$ & $9(8.0 \%)$ \\
\hline
\end{tabular}

${ }^{\star}$ Significant association $\mathrm{p}$ value $<.05$

** (Dalit, Janajati, Madhesi and Muslim)

*** (Medicine, surgery, neurosurgery, pediatric, psychiatric, Maternity and Operation theatre) 


\section{DISCUSSION}

$\mathrm{T}$ his study showed that $76.1 \%$ of the respondents were from age-group 21-15 years, this study is similar with the research conducted at Chitwan Medical College, Nepal by (Karki et.al, 2015) which revealed that most of the respondents (58\%) were 20-25 years of age group. Regarding respondent's ethnicity, more than half $(53.1 \%)$ of the respondents belonged to Brahmin/Chettri which was similar to the study conducted by (9) which showed most of the respondents (74\%) were Brahmin/Chettri. Concerning the work experience, most of the respondents (94.7\%) worked for 1-5 years which was similar to the findings of the study conducted by (9) which showed $50 \%$ of the respondents had 5-10 years of clinical exposure. In relation to the training, none of the respondents ever received the training on organ donation before.

This study contradicts with the cross-sectional study conducted in Turkish University by 10 which showed $66.1 \%$ of the respondents received training on organ donation. This may be attributed to the insufficient trained professionals, infrastructures, hospital policy and different social set up in two countries. In this study, most of the respondents (71.7\%) were in support for organ donation which was similar to the findings of the study conducted in Punjab, India by (11) which revealed $75 \%$ of the respondents were in favor of organ donation.

In this study, less than half (44.2\%) of the respondents were willing to donate organs after death which contradicts with the findings of the study conducted in Karnataka, India by 12 which revealed more than half $(57.3 \%)$ of the respondents were willing to donate their organs only after death. The variation of the findings may be attributed by the difference between number of samples, settings and social context of two countries.

The findings in this study showed $69.9 \%$ of the respondents have average knowledge followed by inadequate $(23.9 \%)$ and only $(6.2 \%)$ adequate knowledge regarding organ donation which is consistent with the findings of the study conducted in India by 11 which revealed $74.5 \%$ of the respondents had average knowledge, $22 \%$ had poor and only $3.5 \%$ had good level of knowledge. Another similar study conducted by13 also showed (71.8\%) of the respondents had average level of knowledge regarding organ donation.
This study showed $99.1 \%$ of the respondents had positive attitude regarding organ donation which is supported by the study conducted by 15 which revealed almost all (99\%) medical students had positive attitudes regarding organ donation and transplantation. Another study conducted in Chitwan Medical College by 9 also showed $(94 \%)$ of the respondents had positive attitude regarding organ donation.

In this study, less than half (27.4\%) of the respondents agreed to donate family member's organ which is similar with the findings of the study conducted in Turkey by10 which showed (38.8\%) of the respondents were willing to donate organs/tissue of their relatives. The findings of the present study showed the level of knowledge is not associated with age group, academic year and sources of information which is similar to the findings of the study conducted in Hongkong by 13 which showed no associations are observed for age, study program and education level.

In the current study, there is an association between ethnicity $(p=0.026)$ with the level of knowledge which is supported by the similar study conducted in Malaysia by14 which shows the level of knowledge is significant with the ethnicity $(\mathrm{p}=0.018)$. Similarly, in this study the level of knowledge is not associated with the training which contradicts the findings of the study conducted in a Turkish University by 10 which showed significance differences between organ donation and received training $(\mathrm{p}<0.05)$. The variation of the findings may be attributed due to lack of appropriate training programs, provision of trained professionals in organ donation and hospital policy compared to developed countries.

\section{CONCLUSION}

$\mathrm{T}$ his study concluded that more than half of the respondents had average level of knowledge and almost all respondents had positive attitude regarding organ donation. The level of knowledge was associated with ethnicity whereas there was no association between level of knowledge and other socio-demographic variables. The study showed most of the respondents gained information from colleagues followed by academic curriculum, television, family neighbors, internet and least from radio. The study also revealed none of the respondents ever received training regarding organ donation. 


\section{REFERENCES}

1. Khan N, Masood Z, Tufail N, Shoukat H, Ashraf KTA. Knowledge and attitude of people towards organ donation. JUMDC [Internet]. 2(2):15-21. Google Scholar | Full Text

2. Kumar V, Ahlawat R, Gupta AK, Sharma RK, Minz M, Sakhuja V, et al. Potential of organ donation from deceased donors : study from a public sector hospital in India. Transplant International. 2014;27:1007-14. https://doi.org/10.1111/tri.12355 [Google Scholar] [Full Text]

3. Agimol P. Increasing Organ donation in the North West South Asian Community through targeted education (Master's thesis, The University of Salford, United Kingdom). 2015 Google Scholar | Full Text

4. Chakradhar K, Doshi D, Reddy SB, Kulkarni S, Reddy M, Reddy S. Knowledge, Attitude and Practice Regarding Organ Donation among Indian Dental Students. International Journal of Organ Transplantation Medicine. 2016;7(1):28-35. Google Scholar | PubMed | Full Text

5. Chalise PR, Shah DS, Sharma UK, Gyawali PR, Shrestha GK, Joshi BR, et al. Renal Transplantation in Nepal : The First Year' s Experience. Saudi Journal of Kidney Diseases and Transplantation. 2010;21(3):559 64. Google Scholar | Full Text

6. The Human Body Organ Transplantation (Regulation and Prohibition) Act, 2055 (1998). Full Text

7. Ilango S, Nandhini MMU, Manikandan S, Sembulingam P. Awareness of Organ Donation among Fresh Students in Medical. International journal of medical science and clinical Invention [Internet]. 2014;1(6):274-83. Google Scholar | Full Text

8. Agrawal S, Binsaleem S, Al-homrani M, Al-juhayim A. of Kidney Diseases and Transplantation Original Article Knowledge and Attitude towards Organ Donation among Adult Population in Al-Kharj, Saudi Arabia. 2017;28(1):81-9. https://doi.org/10.4103/1319$\underline{2442.198150}$ Google Scholar | Full Text
9. Karki S, Thapa S, Poudyal S. Original Research Article:Knowledge And Attitude Of Nursing Students Regarding Organ Transplantation. Journal of Chitwan Medical College. 2015;5(13):60-5. https://doi.org/10.3126/jcmc.v5i3.16528 [Google Scholarl | Full Text

10. Cebeci F, Dag GS, Karazey E. Undergraduate nursing students 'opinions and attitudes toward organ donation : a survey in a Turkish. Journal of Nursing Eucation and Practice. 2015;5(9):83-9. https://doi.org/10.5430/jnep. v5n9p83 Google Scholar | Full Text

11. Kaur S, Ghai S, Krishnan N, Rana D, Kathania D, Kaur G, et al. Knowledge , Attitude and Perception Regarding Organ Donation among the Nursing Students. JPMER.2015;49:105-10. https://doi.org/10.5005/jp-journals-10028-1157 PubMed | Full Text

12. Bathija G V, Ananthesh BG, Bant DD. Study to Assess Knowledge and Attitude towards Organ Donation among Interns and Post Graduates of a Medical College in Karnataka, India. 2017;8(5):236-40 Google Scholar | Full Text

13. Tam WWS, Suen LKP, Chan HYL. Knowledge, Attitude and Commitment toward Organ donation among Nursing Students in Hongkong. Transplantation Proceedings. 2012; 44:1196-1200. https://doi. org/10.1016/i.transproceed.2012.01.108 Google Scholar | Full Text | CrossRef

14. Huern SY, Choo K, Yee S, Rajah JS, Ponniah MP, Ikmal M, et al. Knowledge, Awareness and Attitudes on Organ Donation among Undergraduate Medical Students in Malaysia: An Analytical Cross Sectional Study. British Journal of Medicine \& Medical Research. 2016;16(3):1-14. https://doi.org/10.9734/ BJMMR/2016/26208 Google Scholar | Full Text

15. Chung CKY, WK Ng C, YC Li J, Sum KC, Man AH, Chan SP, et al. Attitudes, knowledge, and actions with regard to organ donation among Hong Kong medical students. Hong Kong Med J 2008;14:278-85 [Internet]. 2008;14(4):278-86. Google Scholar | Full Text 